Memorial to the Late Dr. A. T. R. Mattick, C.B.E.

Colleagues and friends of the late Dr. A. T. R. Mattick, for many years head of the Bacteriology Department and deputy director of the National Institute for Research in Dairying, University of Reading, wish that some form of memorial be established to commemorate his work and perpetuate his name. Everyone who knew Dr. Mattick will be aware that he set himself high standards in his scientific work and in its presentation. They will also remember that he always had in the forefront of his mind the benefits to the Institute's research programme which came from discussion with seientists in other research centres both at home and abroad. It is proposed, therefore, to establish a memorial fund, the income from which, in the absence of financial support from other sourees, would be used to enable members of tho research staff of the Institute to visit research centres either in the United Kingdom or abroad or to attend specialist conferences. It might also be appropriate on occasion to invite a distinguished scientist to give a memorial lecture on a topic which would be of interest to people connected with dairying. Individuals and organizations within the dairy industry who have reason to be grateful to Dr. Mattick for his help and guidance would no doubt wish to be associated with this proposal and to subscribe towards a fund to commemorate the life work of a man who is spoken of as "the father of dairy bacteriology". Contributions towards the Memorial Fund should bo sent to the Director, National Institute for Research in Dairying, Shinfield, Reading.

\section{Bicentenary of the Birth of John Dalton}

THE bicentenary of the birth of John Dalton falls in September 1966, and to mark the occasion a programme of events will bo hold in Manchester, where Dalton lived and worked for most of his life. The celebrations are being sponsored by tho Royal Society, the Manchester Literary and Philosophical Society, the Chemical Society, the Royal Institute of Chemistry and the Society of Chemical Industry, with the collaboration of the British Society for the History of Science and the Director of the Science Museum. The detailed arrangements are being made by the Manchester Literary and Philosophical Society. Although tho details aro not yet fixed, the colobrations will probably be held during the third week in September 1966, and are likely to consist of a specialist conference for the historians of science, followed by a series of meetings of more general interest. The programme will include an exhibition and a number of social events.

\section{Science and the Policies of Governments}

Science and the Policies of Governments presents the report of the ad hoc Advisory Group on Science Policy of the Organization for Economic Co-operation and Development (Pp. 55. Paris: Organization for Economic Cooporation and Dovolopmont, 1963). The Group was appointed in 1961 by the Secretary-General to advise him on policy issues of science and technology that are increasingly demanding attention from Governmonts and the scientific community, as well as on the general orientation and long-term objectives of the Organization in this field. The Advisory Group, of which M. Pierre Piganiol was chairman and Sir Willis Jackson a momber, after reviewing generally the new dimensions of science and technology, the public stake in science and the relation of science to oconomic growth and objectivos, points out that science policy is not an abstract concept but of the same nature as economic policy or foreign policy. There has devoloped on Governments a major and continuing responsibility to make choices about the issues that involve science. The second part of the report discusses science and national policy, including its bearing on scientific policy and on other factors that enter into the effective management and pursuit of scientific work and scientific communication, as well as some of the implications of science in making economic or foreign policy or its bearing on manpower and educational policy. This section of the report insists on the need to formulate a national policy for science, to co-ordinate the various sciontific activities of a country, and to integrate science with general policy, and advocates the constitution for these purposes of a Science and Policy Office, the specific functions of which are detailod. From this, in the third part of the report, the Group proceeds to a discussion of international affairs, emphasizing first the need for policy and recommending specifically for the Organization for Economic Co-operation and Development a meeting of Ministers for Science. The agenda visualized would be concerned with national science policy, the concept of which should be clarified; with international seientific co-operation; and with science, economic growth and the role of the Organization for Economic Co-operation and Dovelopment. [Such a moeting was, in fact, hold in Paris during October 3-4, when the report was considered.]

\section{London and Home Counties Regional Advisory Council for Technological Education}

THE fourteenth annual report of the London and Home Countios Regional Advisory Council for Technological Education, covering the period from September 1, 1961, to December 31, 1962, claims that the Council is a vital link in the chain of communication and partnership between education and industry ( $\mathrm{Pp} .39$. London: London and Home Counties Regional Advisory Council for Technological Education, 1963). Thē Council has been intimately connected with many developing features of technical and technological education, and a working party, sponsored by the Council and the Institute of Education, University of London, has just comploted a report on educational research into technical education. Concern is expressed as to the effect on the constitution and functions of the Council of the Government proposals for the reorganization of local government in Greater London. Some 289 courses were supported during the year, 51 being in applied science and mathematics, 98 in engineering and 140 in other subjects. Twelve colleges in the region have been recommended for designation as regional colleges, with a reserve list of three others for future designation. Reports from the Regional Academic Board, the Distribution of Courses Committee and the fifteon Regional Advisory Committees are included.

\section{Centralization and Documentation}

A FINAL report to the National Science Foundation made by Arthur D. Little, Inc., on Centralization and Documentation, dated July 1963, does not support the large-scale contralization of facilitios for storing and retrieval of scientific documents at the present time (Pp. iv + 70. Cambridge, Mass.: Arthur D. Little, Ine., 1963). It is considered that a large centralized facility drawing on present-day techniques for retrieving documents is unlikely to achieve the main objective of providing an effective exhaustive capacity for searching the litera. ture to supplement offorts to provent duplication of research or development. The report recommends, however, a comprehensive programme to indicate the real noods of scientists and engineers for information. Such a survey, conducted with imagination and insight, is an essential pre-requisite to the support of any centralized searching facilities in future, if such facilities are to serve useful functions. Before extensive efforts are mado to develop such aids as elaborate word thesauri for existing retrieval systems, the report recommends also the further investigation of the use of statistical techniques for the automatic generation of thesaurus lists and for the auto. mation of some functions at present performed by human intermediaries. To this end, the report suggests that one of the existing medium-sized co-ordinate retrieval systems should be operated experimentally on a statistical 